\title{
Dia Mundial da Criança
}

O Dia Mundial da Criança, oficialmente, é 20 de novembro, dia em que a ONU reconhece como Dia Universal das Crianças por ser a data em que foi aprovada a Declaração dos Direitos das Crianças, porém, a data efetiva de comemoração varia de país para país. No Brasil é no dia 12 de outubro. 